\title{
Analysis of interrelation of financial results and financial condition of the company
}

\author{
Lyudmila Adamaytis ${ }^{1, *}$, Nadezhda Zonova ${ }^{1}$, Elena Petrova ${ }^{1}$, Nadezhda Palesheva ${ }^{1}$ and \\ Natalia Gritsuk ${ }^{1}$ \\ ${ }^{1}$ Vyatka State University, Preobrazhenskaya St., 41, 610020 Kirov, Russia
}

\begin{abstract}
The article deals with the fundamental categories of company analysis in a market economy such as its financial results and financial condition. Special attention is given to the study and justification of the mutual influence and dependencies between them with the help of formalized analytical models, non-formalized logical and empirical studies and conclusions. In particular, the authors of the article justify the mechanism of the influence of profit and profitability on bankruptcy risks. They underline the importance of obtaining the required amount of profit and the correctness of its use. Moreover, the authors propose criteria for evaluating the rational distribution and use of the company's net profit. The influence of the profit capitalization factor is confirmed by the example of a model of sustainable economic growth. The authors emphasize the importance of the issues under consideration in the development of management decisions, including the formation of dividend policy. The article also presents the authors' approach to some methodological aspects of analyzing the use of profits. The research is based on the financial statements of Russian construction companies. However, these models can be applied to commercial companies in other fields of activity.
\end{abstract}

\section{Introduction}

Financial results and financial state are the major categories reflecting success and stability of functioning of the commercial company in market conditions. Key question of the analysis is identification of their interrelation and justification of the directions of mutual influence for making the correct administrative decisions. The financial condition of the company reflects the final results of its activities that are of interest to the owners (shareholders), business partners, and regulatory bodies. Among numerous factors of ensuring financial stability of the company, the financial results are especially significant. It should be noted that the problem of assessment of their influence on a financial state is important both at a stage of formation of profit and at a stage of its use. Especially, it is necessary to emphasize dependence of a financial state on dividend policy of the company. Scientists - analysts pay great attention to the analysis of financial results and financial

\footnotetext{
*Corresponding author: kafinanc@yandex.ru
} 
condition. However, the mechanism of their interaction requires separate studying and development.

\section{Methods and Materials}

To substantiate the relationship and interdependence between financial results and financial condition, empirical studies were conducted. Formalized methods and models were analyzed: probability models (risks) of E. Alman's bankruptcy, Russian scientists of the Irkutsk State Academy of Economics, R. Saifilin and G. Kadykov (Moscow State University named $M$. Lomonosov). The influence of the reinvestment policy on the financial condition was studied using non-formalized logical research methods, as well as using a deterministic factor model of economic growth sustainability. Materials for research and publication were the own developments of the authors and the work of Western and Russian scientists.

\section{Results}

Financial results are the absolute amount of profit (or loss) and relative profitability. Stable profits provide an opportunity for self-financing and scaling up. Getting and raising profits is the goal of any business. However, according to Professor V. Kovalev, an equal amount of profit may be the result of various capital investments and sales volumes [2].

Profitability is the most objective criterion, as it reflects the interrelation of profit with sales volumes, current expenses and capital invested in a business. We can assume that profitability is an integrated indicator of business performance in a market economy, since it combines all the factors affecting the company's operations. Depending on the objectives of the analysis and management objectives, the company evaluates the entire range of profitability indicators: GPM, ROS, NPM, RCA, RFA, ROI, ROA, ROIC, ROE, etc. [1, 4, $5,6,7]$. With regard to financial status, the lack of equal approaches regarding the economic content of this category should be noted. This applies to both foreign and Russian financial analysts $[1,4,5,7-14]$

Let's not conduct a comparative analysis of the essence of the concept of financial condition. It should be noted that the essence of stable financial condition is determined by the rational formation, distribution and efficient use of financial resources that ensure the necessary development of the company, long-term preservation of its financial stability, solvency, and ability to withstand risks. From a practical point of view, the financial condition is assessed in accordance with the system of financial and analytical indicators reflecting financial independence and financial leverage, availability of own working capital, liquidity and debt, rationality of cash flows, etc.

To ensure financial stability, it is important not only to get the necessary amount of profit, but also to use it correctly. Real increase in equity is through the capitalization of profits. Therefore, in each case, it is necessary to choose the most rational option for the distribution of profits and dividend policy.

\section{Discussion}

The financial condition of the company largely depends on the size of profit and profitability. Note that high profitability also ensures the financial stability of the company. But, except this empirical conclusion, the interrelation of financial results and a financial 
state is confirmed by the formalized models, in particular, the known models of diagnostics of risk of bankruptcy. [15, 16, 17, 18, 19, 20, 21. 22]:

- Model of Altman (for the large companies having quotations at the exchange):

$$
\mathrm{Z}=1,2 \mathrm{~K}_{1}+1,4 \mathrm{~K}_{2}+0,6 \mathrm{~K}_{3}+1,0 \mathrm{~K}_{4}+3,3 \mathrm{~K}_{5},
$$

Where, $\mathrm{Z}$ - meaning " $\mathrm{Z}$-accounts" probabilities of bankruptcy;

$K 1$-relation of net turnover capital to assets $(N W C / T A)$;

$K 2$ - the relation of the retained (reinvested) earnings to assets (NP-Div / TA);

$K 3$ - the relation of market capitalization of the company to the loan capital;

$K 4$-turnover of assets $(N S / T A)$;

$K 5$-profitability of assets as the relation of operating profit before payment of interest and taxes to assets $(E V I T / T A)$.

The modified model Altman (for the companies, which stocks are not at the exchange market):

$$
Z=0,717 K_{1}+0,847 K_{2}+3,107 K_{3}+0,42 K_{4}+0,995 K_{5}
$$

Where, K1-relation of net turnover capital to assets $(N W C / T A)$;

$K 2$ - the relation of the retained (reinvested) earnings to assets (NP-Div / TA);

$K 3$-profitability of assets as the relation of operating profit before payment of interest and taxes to assets (EVIT / TA);

$K 4$ - the equity relation to obligations $(E Q / T L)$;

$K 5$ - turnover of assets (NS / TA).

Forecasting model of risk of bankruptcy of the Irkutsk state economic academy:

$$
R=8,38 K_{1}+1,0 K_{2}+0,054 K_{3}+0,63 K_{4},
$$

Where, $R-$ " $R$-criterion" value of risk of bankruptcy;

$K 1$ - relation of own working capital to assets;

$K 2$-true profitability of equity (relation of net profit to equity);

$K 3$ - turnover of assets (ratio of sales revenue to assets);

$K 4$ - profitability of the payed expenses (the relation of net profit to expenses in primary activity).

The Model of R. Saifullin and G. Kadykov's:

$$
R=2,0 K_{1}+0,1 K_{2}+0,08 K_{3}+0,45 K_{4}+1,0 K_{5},
$$

Where, Kl-relation of own working capital to current assets;

$K 2$ - coefficient of the current liquidity (the relation of current assets to short-term obligations);

$K 3$ - turnover of assets (ratio of sales revenue to assets);

$K 4$ - profitability of sales (the relation of profit on sales to revenue);

$K 5$ - profitability of equity (the relation of net profit to equity).

We will note that at each of these models (and many others) there are profitability indicators, and with rather big weight (at models E. Altman at them the biggest weight coefficients (3,3 in the first model and 3,107 - in the second). Models demonstrate existence of correlation dependence between financial results (in this case profitability) and financial stability.

The effect of the absolute values of financial results (net profit or loss) on the financial condition is reflected in the change in the company's equity capital due to the growth or decrease in retained earnings. However, it is impossible to speak about complete and equivalent dependence. The great influence is exerted by policy of distribution of profit 
(dividend policy). The real gain of the saved-up retained earnings occurs not for the total amount of the got net profit, but for the sum of its capitalization.

According to the Russian accounting standards, net profit can be used on various purposes:

- $\quad$ contributions to reserve fund (capital);

- payment of dividends in joint-stock companies (income to participants (founders) in the companies of others organizationally - legal forms);

- a covering of losses of last years;

- replenishment of authorized capital (it is usually made at the expense of the saved-up retained earnings);

payment of rewards (awards to workers following the results of a year, bonuses to top management of the companies and others);

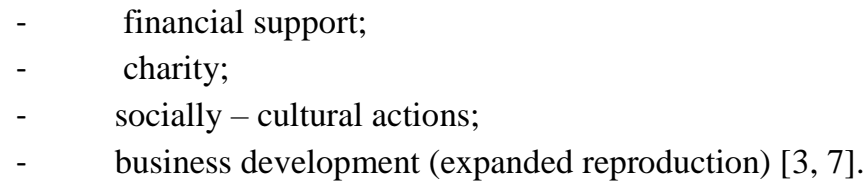

The direction of the distribution and use of profits is determined by the company independently in the manner prescribed by the constituent documents, financial plans and in accordance with the law (in Russia, contributions to the reserve fund amount to 5\% of the net profit and $5 \%$ of the amount of the authorized capital). The main purpose of the analysis of the distribution and use of profits is to assess the rationality of the company's reinvestment policy. Reinvested (capitalized) profit is the value of the net profit of the reporting year, which goes into business development, increases the company's own capital and assets. The profit consumed includes the amount of accrued dividends and the use of profits for other purposes not related to investing in a business (material encouragement and assistance, charitable, socio-cultural, and other similar purposes). Thus, through consumption channels, the profit is spent and its size decreases in the balance.

The main part of capitalized profit is retained earnings - it remains in circulation and is the main source of expanded reproduction. If part of the profit was used to replenish the reserve fund, authorized capital and to cover losses of previous years, then these amounts are also included in the capitalization of profits. The distribution of net profit is the main issue of dividend policy in a joint-stock company. Professor V.I. Barilenko notes that the complexity of his decision lies in the fact that there are obvious advantages both from the position of profit capitalization (growth in the company's value, business expansion through its own, cheaper sources of financing) and from the position of shareholder welfare and stability of dividend payments. The author considers that there are no unambiguous criteria [6]. We believe that the reinvestment policy as a whole can be considered rational if the share of capitalized profit is at least $50 \%$ of the total amount of the net profit of the reporting year. Thus, a significant proportion is used for consumption purposes - up to half of the total amount of distributed profits.

Quite often, a simplified approach to calculating profit capitalization is proposed as the difference between net profit and dividends. However, this is justified if the profit consumed is represented exclusively by dividends. This situation corresponds little to practice, since significant (sometimes prevailing) payments from profits are not associated with dividends, but with bonuses to attracted top managers who are not shareholders of the company, and with other channels of "eating away" profits. Certain difficulties of analysis are related to the fact that the distribution of profits occurs in the year following the reporting year. In this situation, the external user can estimate the proportions in the 
distribution of profits for the reporting year only approximately (for example, based on the analytical note to the annual report on the planned use of profits). Otherwise, the analysis of this issue should be postponed until the moment when the relevant operations will be reflected in the accounting and reporting (for example, until the shareholders meeting or reporting for the first half of next year). Alternatively, the share of capitalized (or consumed) profit in the net profit of both the reporting and the previous year should be estimated. Sometimes the company management determines a high dividend payout percentage as quite acceptable, based on the size of the net profit of the previous year. But at the same time, it does not sufficiently take into account the risks of reducing the financial result in the current (reporting) year and allows for a negative situation of excessive consumption of profits. Therefore, when forming the dividend policy, it is necessary to properly plan sales and financial results of future periods, taking into account risk factors.

The influence of the dividend policy (or the policy of distribution / use of profits) on the financial condition and development of the company can also be proved using factor models:

- first, the corresponding factor is present in both models of Altman. This is an indicator of $\mathrm{K} 2$, and it occupies the second place with rather large weight coefficients;

- second example, the sustainability model of a company's economic growth[2, 3, 5, 6, $8,10]$.

$$
R R=P C \times N P M x T A T x C S,
$$

Where, $R R$ (Return on Revenue) - the coefficient of sustainability of economic growth (the ratio of capitalized profits to equity);

$P C$ (Profit Capitalization)- profit capitalization ratio (ratio of capitalized profit to net profit);

NPM (Net Profit Margin) - net profitability of turnover (the ratio of net profit to revenue);

TAT (Total Assets Turnover) - asset turnover (ratio of revenue to total assets);

CS (Capital Structure) -is a capital structure multiplier (the ratio of all assets to equity capital. The inverse of financial independence ratio (Financial independence $=1$ - Debt ratio).

Thus, the growth of the company is not only due to the size and efficiency of resource use, but also the level of reinvestment of profits.

\section{Conclusions}

Thus, the real increase in equity in terms of accumulated retained earnings occurs in the amount of its capitalization. Of course, the factor of profit capitalization is not the only one to ensure a stable financial condition and development of the company. But it is extremely important and should be taken into account when making management decisions. All concepts of dividend policy should be interconnected and aimed at developing an optimal balance between maximizing the welfare of owners and ensuring adequate funding for current and investment activities. When developing management decisions, it is necessary to coordinate the company's reinvestment policy with its current financial condition and to justify the possibilities of a more rational use of profits. In particular, with insufficient financial stability and solvency, it is advisable to consider part of the profit intended for consumption as a potential reserve, which, with a more rigid capitalization option, can be used to replenish its own working capital and capital in general. A tougher capitalization of profits should be considered as a safety margin or "safety cushion" in the event of deteriorating market conditions and forecasting crisis phenomena in the company and the 
economy as a whole. Irrational use of profit (directing it mainly to consumption / dividends) can have the same negative effect on financial condition as losses in loss-making companies. With regard to the latter, it can be concluded that their own sources of development are reduced (absent), their own capital is reduced and financial stability is weakened. In this case, the focus should be on loss factors and the rationale for their elimination. In the article, we focused on the impact of the financial results of the company on its financial condition, including issues of bankruptcy risk and sustainability of economic growth. However, feedback cannot be excluded - the higher the financial stability, the higher the competitiveness of the company, ceteris paribus, and the possibility of obtaining and increasing profits.

\section{References}

1. L.A. Bernstein, Financial statement analysis: theory, application and interpretation, 4th ed. (Homewood, Irwin, 1989)

2. V.V. Kovalev, Financial analysis: methods and procedur (Finance and statistics, Moscow, 2006)

3. A.V. Zonova, L.A. Adamaytis, Accounting and analysis (INFRA-M, Moscow, 2016)

4. M.V. Melnik, V.V. Berdnikov, Financial analysis: the system of indicators and methodology (Economist, Moscow, 2005)

5. O.V. Efimova, Financial analysis: modern tools for economic decision-making (Publish. house "Omega-L", Moscow, 2009)

6. V.I. Barilenko, Analysis of financial statements (KNORUS, Moscow, 2016)

7. V.N. Edronova, M.V. Shahmatov, Economic analysis: theory and practice 13(28), 2-8 (2004)

8. D.A. Endovitsky, Economic analysis: theory and practice 5, 7-13 (2005)

9. L.A. Adamaytis, Types of financial stability: methodical aspect 1 (2017)

10. A.V. Grachev, Audit and financial analysis 3, 390-397 (2012)

11. V.G. Kogdenko, Methodology and methods of economic analysis in the management system of a commercial organization (UNITY-DANA, Moscow, 2008)

12. J.A. Ou, S.H. Penman, Journal of Accounting and Economics 11(4), 295-329 (1989)

13. A.D. Sheremet, Audit and financial analysis 3-4, 152-163 (2017)

14. G. Rodrigez-Perez, J. Slof, M. Sola, et.al. ABACUS 47(1), 61-84 (2011)

15. D.A. Endovitsky, Diagnostic analysis of the financial insolvency of the organization (Economist, 2007)

16. M.S. Fridson, A.F. Alvare, Financial Statement Analysis: A Practitioner's Guide (John Wiley \& Sons Inc., New York, 2002)

17. J.A. Ohlson, Journal of Accounting Research 18(1) (1980)

18. L.A. Adamaytis, E.V. Petrova, Economy and management: problems and solutions 1(9), 85-92 (2017)

19. T.J. Linsmeier, Accounting Horizons 25(2), 409-417 (2011)

20. S.A. Meshkov, G.V. Meshkova, Economic science 1, 41-43 (2016)

21. E.V. Negashev, Audit and financial analysis 5, 110 - 121 (2010)

22. I.E. Risin, Y.I. Treshevsky, Economic analysis: theory and practice 3, 21-26 (2004) 